\title{
Local Democratic Crises in Sri Lanka: A Study based on Kalmunai Municipal Council
}

\section{Mohamed Anifa Mohamed Fowsar}

\author{
Senior Lecturer in Political Science, \\ Department of Political Science, \\ Faculty of Arts and Culture, \\ South Eastern University, Sri Lanka
}

DOI: https://doi.org/10.36941/jesr-2020-0085

Abstract

Local democracy is a popular concept that is most applicable at the grassroots level. If the local government has a strong standing in local democracy, it can legitimately claim to play a significant and distinctive role in the central government. Against this backdrop, this study attempts to analyse the function of local democracy in Kalmunai Municipality in Eastern Sri Lanka. This study is based on a descriptive method of inquiry. The data were collected from both primary and secondary sources of information. In the collection of primary data, the tools and techniques of qualitative research, such as observation, interviews, structured questionnaire, focus group discussions, and field visits were employed. The qualitative interviews were conducted with representatives, voters, and civil society members. Secondary sources such as published and unpublished records, both from different levels of government and from non-governmental organizations, were perused to collect relevant data. The findings of the study show that Kalmunai Municipal Council is struggling to establish a well-built democracy in its territory through people participation at a broader level. The major reason for the declining standard of democratic governance appears to be a distinct drop in the perceived efficiency and effectiveness of the council, issues that have not been addressed by the council. The grossly inadequate powers and resources available to it have made the council incapable of tackling even the underlying day-to-day problems of the local communities.

Keywords: local democracy, local government, municipal council

\section{Introduction}

Local democracy is a popular concept, and it is arguably the most crucial factor in the viability of any modern democracy. This concept is most relevant at the local level, particularly in local government bodies. Generally, the local government is not distinguished by the services it provides, vital though they are to its functioning. The strength of local government depends; therefore, on the role, it plays in local democracy, and on that basis, it gains its legitimacy (Baral, 2004).

Most scholars have discussed the concept of local democracy by associating it with the original idea of democracy. In their view, if elements of democracy are working at the grassroots level, it may justly be identified as local democracy. Based on a similar argument, an UN-HABITAT research on Local Democracy and Decentralisation in East and South Africa (2002) has observed that "Local democracy is a viable political and development process that allows for cross-fertilisation of ideas, resources and decisions required for good governance." Further, this research has showed that for 
local democracy to prevail, there must be the presence of an active civil society, enabling legislation, a fair local electoral system, free access to information and an administrative structure that facilitates this process.

Thus, the central idea of local democracy is the inclusion of different social groups in the political structure and the active participation of citizens in the governance process (Bassey et al., 2013). In a broad sense, Gellner and Hachhethu (2008) have identified four key characteristics of local democracy. They are "citizenship and community, deliberation, political education, and good governance and social welfare". Further, they argue that for a long time, South Asian elites not took seriously local democracy. In the Sri Lankan context, reforming the state has been a recurrent theme in political debate ever since the dawn of national independence in 1948 (Uyangoda, 2012).

The history of local government and decentralisation in Sri Lanka (or Ceylon as it was known then) began even at the time the British occupied the island. But beginning from 1977, Sri Lanka stepped up attempts to incorporate the concepts of decentralisation and democratic governance into her development. It was considered as essential to first bring to an end the conflict that was raging in the country in order to facilitate the participation of ordinary people in development activities and establish good governance at the grassroots level. However, all these efforts to incorporate the principles of local democracy and decentralisation were practically not successful in Sri Lanka.

The elected local councils represent the lowest tier of the governmental hierarchy in Sri Lanka, which includes the Municipal Council, Urban Council and Pradeshiya Sabha. These councils are established according to the socio-economic development of the region (Hettige, 2008). Current studies show that these councils are in a state of crisis. As a result, there is a consensus in Sri Lanka that the country's local government system requires reform (Uyangoda, 2012). In this backdrop, this study attempts to analyse the functioning of local democracy by exploring the local democratic crises based on the Kalmunai Municipal Council in Eastern Sri Lanka.

\section{Review of Literature}

Local government and local democracy are the key conceptual ideas in this study. However, it is a crucial question as to how one may define these concepts correctly. Literatures covering those concepts describe them from different perspectives. However, the following review provides a proper conceptual explanation that is relevant to this study.

Local government is a key institutional framework that is analysed from the perspective of local governance. Local government means the governance of a locality. It usually has general jurisdiction and is not confined to the performance of any specific function. Similar to the above literal meaning, L. Golding has given a simple definition of local government. To him, local government is the management of their own affairs by the people of a locality (as cited in Sharma, 2004).

Local government is essential for democratic achievements, and it adds more value to the democratic political system (Sherifi, 2017). According to Bains (1972), "local government is not limited to the narrow provision of a range of services to the community but encompasses within its purview the overall economic, cultural and physical well-being of that community. It denotes both a form of decentralisation of power and local democracy. In this way, the local government is defined as the decentralisation of governance and development, and decentralisation is justified because of its contribution to development" (as cited in Wilson \& Game, 1998).

Local government is valuable not only for the services it renders for the common welfare of the community but also because of the opportunity it places before the citizens to participate freely, intelligently and actively in the government of their local area, thereby enhancing their creative interest, enthusiasm and local patriotism. Further, the local government fulfills all the domestic needs of a civilised community. It also creates among the citizens' personal interest in their common affairs and keeps the field open for their constructive and creative suggestions.

The concept of local democracy is rooted in the political theories of Alexis de Tocqueville and J.S. Mill. According to Tocqueville, the local government is considered the mainstay of local 
democracy. His arguments are presented in both of his well-known publications, 'Democracy in America' and 'The Old Regime and the Revolution'. In his assessment, local democracy functions as a school of political education because it teaches people how to use power democratically before they became national political leaders. De Tocqueville further stated that local democracy is facilitated by the local government (as cited in Uyangoda, 2012).

Another prominent scholar was J.S. Mill. In his book 'Consideration on Representative Government', Mill argued that local government bodies provide many people with the chance to get elected and that by performing local functions, local citizens could obtain a good political education. Hence, Mill pointed out the value of local government in broad-basing opportunities for civic participation and creating conditions for greater social inclusion (as cited in Uyangoda, 2012).

According to M. Wahlberg and M. Geddes, the concept of local democracy includes electoral, representative, decision making and accountability processes. First, the electoral process focuses on the level of participation in local elections. Second, the representative process observes how effectively councillors represent the needs, views and interests of their constituents. Third, the decision making focuses on how the decision-making process influence in democratic governance. Fourth is the accountability process that keeps track of how the institutions and individuals are accountable to citizens and local communities. Kjellberg considered the following four factors as essential: liberty, autonomy or freedom, participation or democracy, and efficiency (as cited in Ehsan, 2002).

Christine Bigdon (2006) has identified a set of indicators such as efficiency and effectiveness, responsiveness and equality, local leadership, transparency and accountability, people's participation, the rule of law, trust in politics, and underlying security, to analyze the level of good governance in Sri Lanka. The particular study focuses on people's perception of institutions at the local level and the challenges of decentralized governance in Sri Lanka.

Thus, local democracy could be defined as the inclusion of different social groups in the political structure and the active participation of citizens in governance. It is also considered as the most crucial element that ensures the viability of modern democracy. It is further defined as a set of democratic institutions and practices functioning at the local level that are essential for achieving decentralisation and citizens' participation. Based on the foregoing conceptual review, the study employed the following theoretical elements efficiency and effectiveness, professionalism of local leadership, equality and inclusion, transparency, accountability, citizens' participation, consensus and rule of law.

\section{Research Method}

This is a descriptive analysis based on qualitative methods of inquiry with the limited application of quantitative techniques. The primary data were obtained through observation, structured questionnaire, informal interviews, focus group discussions and field visits. The necessary information was gathered from casual conversations with the people representatives and other officials of the council, political party representatives, citizens, civil society representatives, community-level organisations and non-governmental organisations associated with local democracy. Hence, individuals were interviewed for getting their opinions on the working of local democracy. Secondary data were collected from the official documents and reports of the Municipal Council, published texts, research articles, research reports, conference publications, journal articles and website references. The data collected for the study from various sources were analysed using qualitative techniques with the limited application of quantitative strategy. Findings of the study were presented in text format. It is also noted that most of the data were collected over the period 2012-2015 for the research purpose. However, some information was added later to enhance the academic value of the paper. 


\section{Kalmunai Town}

Kalmunai is a major town in the Ampara district. It is located on the Eastern coast of Sri Lanka and about 40 kilometers far away from Batticaloa. It is bounded by the Kaluwanchikudy Pradeshiya Sabha to the North, the Bay of Bengal to the East, the Karaitheevu Pradeshiya Sabha to the South and Navithanveli and Sammanthurai Pradeshiya Sabhas to the West.

In April 2002, Kalmunai Town, which was administered by a Pradeshiya Sabha and then Urban Council, was upgraded to the status of a Municipal Council. Kalmunai Municipal Council became the first Municipal Council in the Ampara District and the second Municipal Council in the Eastern Province of Sri Lanka. The functioning of the Kalmunai Municipal Council, which has a concise history compared to the Batticaloa Municipal Councils in the Eastern Province, was not greatly affected by the war in the North and East.

The majority of the population of Kalmunai municipal area comprising the Divisional Secretariats of Sainthamaruthu, Kalmunai (Muslim) and Kalmunai (Tamil) is Muslims. The total population of the town is 100,116 . Of this, $70 \%$ are Muslims, $28.69 \%$ are Tamils, $0.65 \%$ are Sinhalese, and 0.66 are classified as Others. Most of the local inhabitants speak Tamil. Religion-wise, people in the region follow Islam, Hinduism, Christianity and Buddhism. Historically, Muslims and Tamils have lived together in the region for a long time (Kalmunai Municipal Council, 2012).

As mentioned earlier, Kalmunai has three Divisional Secretariats. There are many national and provincial schools in the three Divisional Secretariats. The city is recognized for having some of the better regional education centers. Presently, the Kalmunai Municipal Council is facing several challenges with respect to the economy and employment. The city's economy depends on trade, fisheries, and state and private industries. The economy of the region, which had been lagging during the war, has seen a marked resurgence. In terms of employment, a fair number of people are working in the public sector. Foreign employment is also one of the important income sources of the city, as many residents are working abroad.

\section{Kalmunai Municipal Council}

Kalmunai Municipal Council was established in April 2002 as the $17^{\text {th }}$ Municipal Council in Sri Lanka. A number of local government agencies administered the area before it was upgraded to a Municipal Council. Town Council of Kalmunai (Kalmunai Pattina Sabhai) was created by the Town Council Act No. 3 of 1946. A senior politician of the East, M.S. Kariyappar, held the post as the first Deputy Mayor. In 1977, the Kalmunai Town Council was dissolved and brought under the administration of a Special Commissioner. With the enactment of the District Development Councils Act No. 35 of 1980, the Kalmunai Municipal Council was transformed into a Sub Office of the Ampara District Development Council (Kalmunai Municipal Council, 2012).

The Pradeshiya Sabha system was introduced in Sri Lanka by the Local Authorities Ordinance No. 15 of 1987. Subsequently, the Maruthamunai North Karavaku Grama Sabha, Sainthamaruthu South Karavaku Grama Sabha, Natpitimunai West Karavaku Grama Sabha and Kalmunai Town were merged to form the Kalmunai Pradeshiya Sabha. The first election for the local council was held in 1994. Gazette No. ${ }_{1057 \mathrm{~F} 16}$ was issued in December 1998 in connection with the Kalmunai Pradeshiya Sabha, in terms of which it was dissolved and brought under a special commissioner. Subsequently, Kalmunai Pradeshiya Sabha was upgraded to an Urban Council. However, the election for the Urban Council never took place. Its administration was then brought under the Kalmunai Divisional Secretariat (Kalmunai Municipal Council, 2012).

According to Gazette Notification No. 1188F issued in June 2001, the Kalmunai Municipal Council was established and came into being in April 2002. It became the second Municipal Council in the Eastern Province and the first Municipal Council in the Ampara district. The first election for the Municipal Council was held in 2005. Presently, the council elected at the 2018 Municipal Council election is functioning. 
The Kalmunai Municipal Council administration, which functions under the Municipal Commissioner, consists of several administrative services such as finance, jobs, planning, health and the library. The number of councillors in the Municipal Council is 19. More than three hundred staff are employed to carry out the day-to-day business of the council. Municipal councillors are generally elected by the people to serve for four years. The mixed method of representation is currently used for the council election.

The councillor who leads the council is known as the Mayor of the town. The Municipal Council has a Deputy Mayor as well. They are selected by the winning party or by independent groups that have the majority of seats in the council. The mayor of the town is the chief executive officer. However, a municipal commissioner has been appointed to assist him. The Municipal Commissioner is one of the senior officers of the Sri Lanka Administrative Service. Decisions relating to management are made in the Standing Committees headed by the Municipal Commissioner. At present several standing committees are functioning in the Kalmunai Municipal Council.

Section 40 of the Municipal Council Ordinance lists the general administrative powers of the Kalmunai Municipal Council. These include the appointment of minor staff, acquisition of property, issuing of licences, taking legal action, and preparing a budget. The Municipal Council also has powers to remove unauthorised buildings, provide infrastructure services and acquire land for a public purpose. Section 46 of the Municipal Councils Ordinance delegates the following additional duties to the Municipal Council. These include cleaning and maintaining public roads, widening and overseeing public roads, providing public utility services, and improving public health. Maintenance of public health services, public utility services, development and welfare, cultural development, and law and order are implemented through the elected members of the council and the various executive divisions that come under it, as mentioned previously.

The Municipal Council receives funding from central and provincial governments, such as for the leasing of vehicles and equipment, leasing of buildings, and other fees and donations. In fact, the council has to rely heavily on the central government for its financial needs. The Municipal Council exercises jurisdiction over the social, cultural and infrastructural developments of its territory, but is frequently subject to the interventions of the provincial and central governments. At the same time, there is widespread criticism that the powers vested in these administrative bodies are not sufficient to sustain local democracy in Sri Lanka.

\section{Results and Discussion}

This paper discusses issues of local democracy in Kalmunai Municipal area, based on selected elements such as efficiency and effectiveness, professionalism of local leadership, equality and inclusion, transparency, accountability, citizens' participation, consensus, and the rule of law, which were derived from previous works found in the literatures.

\subsection{Efficiency and Effectiveness}

Based on the data obtained, there is a high level of dissatisfaction with the functioning of the Kalmunai Municipal Council. This is indicated by the lack of efficiency in service delivery and implementation of development programs. The main reasons for this unsatisfactory situation are the lack of autonomy for municipalities to make and implement their own decisions, the lack of coordination and cooperation among internal units, interference of local politicians and political parties, and the lack of political power and physical resources.

Commenting on the efficiency and effectiveness of the Kalmunai Municipal Council, one interviewee said: "Due to conventional political recruiting practices, we cannot fully expect efficiency in the activities of the council or the administrative functions of the council. As far as political representatives are concerned, they are elected based on public support. Educational qualifications and experience are only considered for administrative officers and employees. Councillors do not have 
enough experience and educational qualifications. In this kind of scenario, it is impossible to expect effective actions from such representatives" (Interviewee 2).

However, according to information obtained from relevant authorities, the municipality is engaged in a variety of activities, although it has a lack of adequate powers and resources. The Kalmunai Municipal Council is involved in activities such as environmental protection, maintenance of roads, the lighting of the streets and enhancing the library service. As for public opinion, a significant number of the 100 people surveyed have expressed dissatisfaction with the manner of functioning of the council. Only a small number are satisfied with the operation of the council.

\subsection{Professionalism of Local Leadership}

Information obtained from the residents of Kalmunai town area also reveals their negative perceptions about the performance of the local leadership. The data collected from the interviews indicate that people demand strong professional and political leadership. However, the informants were not convinced that the local political leadership in the particular area could be identified as such. Educators and professionals were unwilling to get involved in politics. Surprisingly, people also did not welcome the political involvement of educated people and tended to support traditional politicians consistently. Local voters also seem to be divided on the basis of political parties, regional divisions, ethnicity, religion, etc. Such trends led to the dominance of the local political elite in the municipal governance process.

Upon taking a closer look at the internal administration of the Municipal Council, one can observe that staff in certain sections are educated. Some of the other employees and representatives of the Municipal Council are not trained to do their work properly. As for the members, a large number of them lack professional expertise. An important finding of the survey conducted in the Kalmunai municipal area on the local political leadership is, "Municipal governance is guided not by internal administrators but by traditional political parties and their leaderships. Unfortunately, such party politics does not allow the local professional leadership to develop the area according to the needs of the people. It appears political parties mobilize the masses for their own political benefits" (Interviewee 4).

An interviewee complaint that "there are qualified leaders who can lead local government institutions but people do not appreciate the need to create new leaderships that are relevant to their particular region" (Interviewee 2). "They continue to focus on strengthening their traditional political leadership. This raises the question of how to create new professional local leaderships" (Interviewee 6). In fact, the need for professional local political leadership is widely accepted. In this regards, many respondents noted that their local governing bodies did not have professional political and administrative leadership. However, a certain section of respondents claimed that professional local political leadership affiliated to political parties did exist while a small number of respondents refused to comment on it.

\subsection{Equality and Inclusion}

Equality and inclusion are prerequisites for the building of local democracy, but the failure of the Municipal Council to successfully incorporate these principles is visible. Allegations of discrimination have been levelled in respect of the distribution of local resources, service delivery and recruitment. Although a fair number of Sinhalese people live in the area, they have no representation in the Municipal Council. It can be observed that there is no proper internalisation of the representation of women. Cultural and social constraints are often attributed to the causes of women's lack of political representation. Moreover, as the politics of the region is being carried on by the dominant traditional parties, the candidates are forced to keep in line with the parties' wishes. And the parties are not so keen on fielding female candidates.

"While the Muslim and Tamil representation of the council is substantially confirmed in terms of 
social inclusion, Tamils are neglected in development programs, social services and municipal staff. The council is discriminatory. The Municipal Councils are not open-minded about street names. The views of Tamil representatives are being overlooked in the council," said an interviewee representing the Tamil community (Interviewee 8). When a Muslim interviewee in the governing body of the Municipal Council was questioned about this, he said "There is no truth to the allegation that the council is discriminating against Tamils. The Municipal Council has, as far as possible, ensured adherence to issues such as equal resource allocation, development program delivery and recruitment among communities" (Interviewee 3 ).

"The argument about social neglect is put forward for political reasons. The council is very interested in working with the Tamil people who are the minority community in our area. The council received the support of many Tamil representatives in past" an interviewee pointed out (Interviewee 7). However, according to data obtained from civil society organisations and focus group discussions, there has been considerable criticism levelled at the municipality's equality process. Some have alleged discrimination in the recruitment and service delivery of the council. It was also pointed out that political factors have a significant impact on the above activities. As for the public opinions obtained through the questionnaire analysis, 59 people stated that the Municipal Council was discriminatory in its operation. At the same time, 28 were satisfied with the egalitarian and social inclusion process of the council. Further, 13 people refused to comment, of whom 10 were Tamils.

\subsection{Transparency}

As mentioned earlier, the local government must manifest transparency in its dealings, functions and duties. However, according to data collected from the Kalmunai municipal area, allegations are being made by the public about the lack of transparency. Transparency in financial management, in particular, is said to be missing. It has been pointed out that "transparency in governance has been called into question due to the exaggerations made about tax collection by the municipality, funding from other sources, and spending on recruitment and development projects" (Interviewee 8).

On the other hand, an interviewee noted that "people's dissatisfaction with the issue of transparency is due to their low involvement in local governance" (Interviewee 10). Another interviewee said, "The Municipal Mayor acts in accordance with the leadership directives of the major parties in the municipality, and he does not act with openness when making decisions and implementing them. Consultations are given only to party loyalists. Programs are introduced to the congregation in advance. People can see no clarity in the functioning of the council" (Interviewee 9). Civil society representatives commenting on this said, "There are certain issues in the functioning of the Municipal Council, and it cannot be said that the council is transparent in all matters. Anyway, the council is impartial in the implementation of development programs. People are unaware of much of the development work that is being done" (Interviewee 12).

"There is corruption in the development activities of the council. The council works under a political agenda. The Municipal Council is not concerned with being transparent and responsible to the people since it has been transformed into a platform to stage a national political power struggle," an interviewee said (Interviewee 11). During a discussion that was held with a member of the ruling party, an interviewee said: "While it is difficult to ensure transparency in all the proceedings of the council, we have succeeded in ensuring as much transparency as is practically possible. Congregation representatives and staff have received clear explanations in this regard" (Interviewee, 3 ).

"Comparatively little corruption is prevalent in our Municipal Council. The functions of the council are made clear to the public, and important decisions are placed on the public notice board. Similarly, the Municipal Council and the administration are very clear on the issue of transparency in all actions of the council" (Interviewee 4). Upon scrutinising the responses relating to transparency in the questionnaire, 65 persons had marked that the openness of the Municipal Council is not good (unsatisfactory). Fifteen respondents reported being able to observe excellent transparency, while 14 respondents stated that it was bad, and o6 of them refused to comment. 


\subsection{Accountability}

One of the main tenets of local democracy is accountability. Internal corporations are considered to be successful only if they can prove their legitimacy by withstanding upward and downward scrutiny. The principle of accountability is also emphasised in the modern ideas relating to good governance. However, the functioning of the Kalmunai Municipal Council in this regard has not measured up to the standard one might reasonably expect. There are many criticisms of the council's accountability process. A focus group discussion revealed that "the council is not accountable to opposition parties and voters. Representatives boycott voters. They also go back on promises made during election times. They are responsible mainly to their political leadership, and not to the citizens" (Focus Group Discussion 1).

Commenting on this, a trade association representative said, "The Municipal Council has not been held accountable for several questionable activities that took place during the period. The lack of transparency in internal conflicts, taxation and management of funds, the lack of adequate supervision of the activities of the members of the council, and the lack of political support are the reasons for deviating from the responsibility of the council to provide detailed information" (Interviewee 7). The mayors of the council and other representatives have declared that they are performing well, but public opinion is sceptical and cynical. According to the results of the questionnaire, 81 people were dissatisfied with the level of responsibility. Whereas 15 respondents expressed satisfaction with the accountability process, four did not comment on the question.

\subsection{Citizens' Participation}

Based on the data collected, the Municipal Council's public participation mechanism has not been successful, despite the wide range of opportunities available for better governance. Likewise, the council does not focus on practices that would stimulate people's participation. In all the decisionmaking processes of the council, there is not much provision for the direct involvement of people. The citizen's interest in the voting and election of their representatives is not acknowledged by the post-election council, judging by its actions and attitude.

While citizens can influence decision making through contact with politicians, by making complaints, joining committees, and attending meetings of civil and religious groups, it is unlikely that citizens' participation in the local governance matters will be significant. For example, no notable improvements have been made in the Kalmunai Municipal Council in respect to women's participation. As already mentioned, there is a lack of political representation of women in the Municipal Council. Although women make up more than one-half of the population within the Municipal limits, there are a few female members in the entire 19-members of the Municipal Council. Women's participation in the decision making and other activities of the council is inadequate. The exclusion of women from local politics is thus the main reason why their social and political problems are not being adequately addressed.

The Municipal Council has received training with the help of non-governmental organisations on participatory education. The Municipal Council is also taking measures for a participatory budget. However, there are conflicts among council representatives regarding the annual payout, and the council is not interested in formally getting people's participation. This can be understood from the controversies over the budget proposals and referendums in recent years. An observer gallery has been set up to ensure public participation during the proceedings of the council. Citizens' participation was observed on certain days when meetings of the congregation were held. On most occasions, however, it could be seen that the area was occupied by only a limited crowd. It is noteworthy that most of the observers were party supporters and journalists, with only a few members of the general public being present during the proceedings of the council.

An interviewee stated that "Lack of effective civil society programs, separation of representatives into groups based on political interests, lack of public awareness, and lack of consultation committees 
are the reasons for the low level of public participation in the decision-making process" (Interviewee 5). It can be observed that public opinion regarding this is not favourable. The results of the questionnaire analysis indicate that 95 percent of respondents have participated in the election. However, 89 respondents indicated that they had no involvement in the alternative process, while o6 were satisfied with their participation. Five persons refused to comment.

\subsection{Consensus}

Collective decision-making and consensus are essential prerequisites for ensuring local democracy in those localities where a pluralistic social order exists. However, the Kalmunai Municipal Council is constantly facing difficulties in reaching agreement on resolutions. An interviewee said, "The opposition is excluded from the development and other decision-making processes. Resolutions are not properly discussed with the opposition before implementation" (Interviewee 7).

It is clear that the council is acting unilaterally, without any consultation with others, on the municipal council's nominations. Commenting on this, an interviewee representing Tamil community said, "Muslims are given more employment opportunities when they hire employees for the Municipal Council. Tamils get very few and only the lowliest jobs (garbage disposal). The ruling party is biased in this regard. Even the opposition parties are reluctant to seek our consensus despite the possibility of building a better Municipal Council by developing better communication with the Tamil side" (Interviewee 8).

However, an interviewee from the ruling party claimed, "Open discussions with the opposition parties and Tamil community representatives are conducted, and decisions are being taken on council resolutions and development plans. In some cases, it is customary to make such allegations against the ruling party when the opposition parties are not satisfied with the decisions taken" (Interviewee 1). According to the public opinion on this, most Tamils who have been issued questionnaires do not accept as fact that the council is acting in a democratic manner. However, a significant proportion of the Muslims who answered the questionnaire agreed that the council is working in harmony with all parties. Their numbers are 45 and 49, respectively. Four of the respondents did not make any comments on this issue.

\subsection{Rule of Law}

One of the main pillars of democracy is the rule of law. It so happens that there is considerable dissatisfaction regarding the rule of law in the study area. The public opinion in the municipal area is that meaningful law enforcement is inadequate and that the law enforcement mechanism is mainly active in unnecessarily interfering in the public life of the residents. This has caused widespread dissatisfaction among citizens on the matter of the rule of law in Kalmunai. In this regard, one interviewee observed that "the Municipal Council has jurisdiction over certain matters over which it can enforce the rule of law. The Municipal Council should not try to assume full authority over it as the central government has the main responsibility for ensuring the rule of law across the country" (Interviewee 4).

People are also dissatisfied with various other aspects of the rule of law mechanism in the study area. It is widely pointed out that the responsible authorities are biased in favour of politicians due to their power and social status. Commenting on this, a civilian said, "We do not have enough confidence in the law enforcement officers of this area. Relevant authorities do not always act as impartial agents in the matter of law enforcement. The respective service is subservient to a certain class of people. Politicians and economic facilitators are free from the clutches of law enforcement authorities" (Interviewee 6).

Considering the popular opinion obtained through the questionnaire survey and analysis, it is clear that a large number of people are dissatisfied with the state of the rule of law in the area. Of the 100 people surveyed, 89 expressed their dissatisfaction with the rule of law, while 8 were satisfied 
with it. Three respondents declined to make any comments.

\section{Conclusion}

Local Governments are considered as the mainstays of grassroots democracy, through which people can broadly participate at a larger level in the governance process. The strength of local government also depends on the pivotal role it plays in the practice of local democracy and it is mainly on that basis it gains its legitimacy. Kalmunai Municipal Council was established primarily to strengthen local democracy within its territory. However, this particular council has failed to build a wellfunctioning local democracy at the grassroots level due to various reasons, such as political interference, scarcity of financial and other resources, lack of awareness among the people, lack of coordination between politicians and administrative staff, as well as corruption, all of which have served to reduce its autonmy, power and capacity. Only if the council considers these issues seriously and makes sincere attempts to correct them it will be possible to strengthen the level of local democracy.

\section{References}

Baral, U.N. (2008). Local democracy and local government: A case study of Dhikur Pokhari Village Development Committee, Kaski, Nepal. In D.N. Gellner, \& K. Hachhethu (Eds.). Local democracy in South Asia: Microprocesses of democratization in Nepal and its Neighbours. New Delhi: SAGE Publications.

Bassey, A. O., Omono, C. E., Bisong, P. O., \& Bassey, U. A. (2013). States and local government areas creation as a strategy of National Integration or Disintegration in Nigeria. Journal of Educational and Social Research, 3(1), 237. Retrieved from http://www.richtmann.org/journal/index.php/jesr/article/view/12112

Beetham, D. (1996). Theorising democracy and local government. In D. King \& G. Stoker (Eds.) Rethinking local democracy. London: Macmillan.

Bigdon, C. (2006). Good governance and conflict transformation in Sri Lanka: A political analysis of people's perceptions of institutions at the local level and the challenges of decentralised governance. Heidelberg: Ruprecht-Karls-Universität.

Department of State Printing, (2001). Gazette Notification No. 1188F - June 2001. Colombo: Department of State Printing.

Ehsan, M. (2002). Rhetoric of local democracy in Bangladesh: An analysis of rural local government. Asian Affairs, $24(4): 44-76$.

Hettige, S. (2008). Local democracy: The Sri Lankan experience. In D.N. Gellner, \& K. Hachhethu (Eds.). Local democracy in South Asia: Microprocesses of democratization in Nepal and its Neighbours. New Delhi: SAGE Publications.

Kalmunai Municipal Council, (2012). Profile of Kalmunai municipal council. Kalmunai: Kalmunai Municipal Council.

Kumar, G. (2006). Local democracy in India. New Delhi: SAGE Publications.

Ministry of Local Government, Democratic Socialist Republic of Sri Lanka (2013). Municipal Councils Ordinance 1947. Sri Lanka: Ministry of Local Government.

Sharma, M. (2004). Local government: Rural and urban. New Delhi: Anmol Publications.

Sherifi, E. (2017). Comparative overview of local government legislation in Albanian-speaking Republics. Academic Journal of Interdisciplinary Studies, 5 (3S1), 86. Retrieved from https://www.richtmann.org/journal/index.php /ajis/article/view/9761

UN-HABITAT (2002). Local democracy and decentralisation in East and South Africa: Experiences from Uganda, Kenya, Botswana, Tanzania and Ethiopia. Kenya: UN-HABITAT.

Uyangoda, J., \& De Mel, N. (Eds.) (2012) Reframing democracy, perspectives on the cultures of inclusion and exclusion in contemporary Sri Lanka. Colombo: Social Scientist Association.

Wilson, D., \& Game, C. (1998). Local government in the United Kingdom. London: Macmillan Press Ltd. 